\title{
1923-1950 YILLARI ARASINDA TÜRKIYYE'DE KENT VE KENTLEŞME OLGUSU
}

\author{
Serdar SAĞLAM*
}

Özet

Bu makalede 1923 yılından itibaren Türkiye'de kent, kentleşme ve imar yasaları ile bu alandaki uygulamalar ele alınmaktadır. Türkiye'de 1950'li yıllara kadar Ankara haricinde yoğun bir kentleşme hareketine rastlanmamaktadır. Türkiye Cumhuriyetinin başkenti olarak ilan edilen Ankara bu tarihten itibaren hızla büyümeye ve göç almaya başlamıştır. $\mathrm{Bu}$ bakımdan şehre ilişkin kanunlar ve planlamalar, imar faaliyetleri ile bu alanlardaki diğer uygulamalar ilkin Ankara çerçevesinde hayata geçirilmiş ve ülkenin diğer kentleri için de model teşkil etmiştir.

İkinci Dünya Savaşı'nın ardından tarımda makineleşme, karayollarının yaygınlaşması, çok partili hayata geçiş ve diğer etkenlerin neticesinde ortaya çıkan kırlardan kentlere doğru göç hareketinin doğurduğu gecekondu olgusu bu tarihlerden daha önce Ankara'da gerçekleşmiştir. Ankara'ya çalışmak üzere gelenler öncelikle iş merkezi ve yerleşik bölgelere yakın yerlerde iskâna açılmamış mahallerde "baraka" adı verilen, 1924 tarihindeki bir yasada da adı geçen ve gecekonduların da öncüleri sayılabilecek olan derme çatma konutlar inşa etmişlerdir. Gecekondular 1950'li y1llardan önce de Ankara başta olmak üzere Türkiye'nin bir kaç büyük şehrinde yaygınlık kazanmıştır.

Anahtar Sözcükler: Kent, kentleşme, Imar yasaları, baraka, gecekondu.

\section{CITY AND URBANIZATION FACT BETWEEN 1923-1950 YEARS IN TURKEY}

\begin{abstract}
In this article, the laws since 1923 regarding urban, urbanization, zoning and applications on these areas are elaborated. Up until 1950's, there was not a significant urbanization movement in Turkey except the city of Ankara. Ankara, which was declared as the new capital city, began to develop rapidly and started to receive migration after the date of being the capital. Laws and plannings regarding the cities as well as construction activities and other applications in urban planning firstly started in the Ankara district and these applications have been a model for other cities.

Just after the end of World War II, the squatter housing phenomena intitially started in Ankara before the squatter housing trend in Turkey which is occured as a result of the internal migration from rural to urban that is stimulated by the mechanization in agriculture, expansion of the highway network, the transition to multiparty regime and other factors.
\end{abstract}

*Doç. Dr., Gazi Üniversitesi, Edebiyat Fakültesi, Sosyoloji Bölümü.

İletişim: serdarsaglam@gazi.edu.tr 
The ones who came to Ankara to work initially built buildings called "baraka" (shanty) in the neighborhoods which are mentioned in a law dated 1924, they were close to business centers and settled areas, and they were located in the areas without building permission, these jerry-built houses can be considered as the pioneers of squatter houses. Squatter houses became prevalent in Ankara and in other big cities of Turkey before 1950's.

Keywords: Urban, urbanization, zoning laws, shed, slum.

\section{Giriş}

Bu makale kuruluşundan 1950'li yıllara kadar Türkiye'deki kentleşme, kentle ilgili yasalar ve uygulamalar çerçevesinde kent ve kentleşme olgusunu tartışmak amacındadır. Türkiye Cumhuriyeti'nin kuruluşundan İkinci Dünya Savaşı'nın sonuçlanmasına ve hatta 1950'li yıllara kadar Türkiye'de çok yoğun ve ciddi sayılabilecek bir kentleşme hareketine rastlanmamaktadır. Bunun yegane istisnasını Ankara oluşturmaktadır. Ankara o dönem içerisinde, başkent olarak ilan edilmesinin ardından bir şantiye alanına dönmüş bulunan, sürekli göç alarak genişleyen, arazi, arsa, konut ve kira bedelleri hızla artan bir şehir görünümündedir. Bu bakımdan bu metinde konunun daha çok Ankara eksenli olarak ele alınması bir zaruret olarak kendisini hissettirmiştir.

Ankara'nın haricinde İstanbul ve İzmir başta olmak üzere o günün büyük şehirlerinde de kentleşme, mimari uygulamalar ve nüfus artışı sözkonusu olmakla birlikte, bunların daha geriden bir seyir izledikleri görülmektedir. Özelllikle İzmir'de 1922'deki büyük yangından ve şehrin tahribatından sonra İstanbul Şehremenati'den dönüştürülen, Ankara için tasarlanan ve bütün ülke genelinde uygulamaya konulan kanunlar ekseninde ciddi faaliyetlerde bulunulmuştur. $\mathrm{Bu}$ faaliyetler 1922 senesindeki büyük yangında tahrip olan bölgeler başta olmak üzere bütün şehir için çok kapsamlı imar planının hazırlanması, konut sorununun çözülmesi ile yeni İzmir'in kurulmasıydı. Rene Danger'in hazırladığı imar planı çok eleştirilmesine rağmen İzmir'i yeni ve modern çehreye kavuşturmuştur. 1923'den 1932 yılına kadar 3000'e yakın yeni konut inşa edilmiş ve yangın yerleri inşaat alanı haline getirilmişti. İzmir'de zarar gören kamu binalarının yerine yapılanlara ilaveten yeni ihtiyaca göre kamu binaları inşa edilmiş ve 1925 yılında Türkiye ile Yunanistan arasında imzalanan "Mübadele" antlaşmasıyla gelen mülteciler İzmir'in bazı bölgeleri ile civar kasabalara yerleştirilmiştir. 1938 yılında da İzmir için beş yıllık imar planı hayata geçirilmiştir (Baran, 2003: 45-208). 
Türkiye'de köy, kasaba ve şehirlerin toplumsal ve hukuki konumlarını belirleyen en önemli metin 1924 tarihinde kabul edilen 442 sayılı "Köy Kanunu"dur. Bu kanunun adı köy kanunu olmasına rağmen, sadece köylerle ilgili olmayıp, şehir, kasaba, ve diğer yerleşim birimlerini de tanımlaması Türkiye'deki köy ve şehir algısını göstermesi bakımından oldukça dikkat çekicidir.

Bu kanunda nüfusu 2000'den aşağ1 yurtlar köy, 2000-20.000 arasında olanlar kasaba ve 20.000'den fazla olanlar da șehir olarak kabul edilmiştir (Resmi Gazete, 7.4.1924, Sayı. 68; Düstur, Tertip: 3, Cilt: 5, sayfa 336).

\section{Türkiye Cumhuriyeti’nin İlk Yıllarında Kent ve Kentleşme}

Türkiye'de gerçekleştirilen ilk nüfus sayımı olan 1927'de nüfusun 13.648.270 kişi olduğu tespit edilmiştir. Buna göre köy nüfusu toplam nüfusun \% 75.78'ine, şehirler ise \% 24.22'sine tekabül etmektedir. Bu haliyle Türkiye'nin kurulduğu tarihlerde bir köy veya kır toplumu niteliğine sahip olduğu görülmektedir.

1950 yılında da kır ve şehir oranı yine çok fazla bir değişikliğe uğramamış görünmektedir. $\mathrm{Bu}$ tarihte de oranlar \% 25'e \% 75 şeklindedir (İstatistik Göstergeler 1923-1990: 7).

Cumhuriyet'in ilk yıllarında Türkiye'de şehirlerin il nüfuslarının da aynı şekilde çok az olduğu nüfus istatistiklerinden anlaşılmaktadır. 1927 yılında Türkiye'de il nüfusu yüz bini geçen sadece iki şehir varken 1945-1960 yılları arasında bu sayı ancak altıya ulaşmıştır (50 Yılda İmar ve Yerleşme 1927-1973, 1973: 7).

\section{Türkiye'de İlk Büyük İmar Hareketi, Göç ve Kentleşme Örneği: Ankara}

Türkiye'de Cumhuriyet'in kuruluşundan 1950 y1lına kadar hızlı bir kentleşme hareketine ve kırlardan kentlere doğru yoğun bir göçe rastlanmamaktadır. Bunun neredeyse tek istisnası Ankara'dır. Ankara başkent ilan edilmesinin ardından büyümeye ve göç almaya başlamıştır. $\mathrm{Bu}$ bakımdan şehirleşme, şehir planlaması, imar faaliyetleri ile şehre ilişkin yeni kanun ve uygulamalar öncelikle Ankara çerçevesinde hayata geçirilmiştir. 
Cumhuriyetin kuruluşundan sonra Ankara'nın merkez nüfusu 72 köyü, 2 nahiyesi ile birlikte 21.445 'tir. 1927 sayımına göre Ankara toplam 74.533 olan nüfusu ile nüfusu 40 binin üzerinde olan 6 şehirden biri olarak dikkati çekmektedir (Sarığlu, 2001: 75-78).

Ankara'nın başkent olarak ilan edilmesinin ardından bu yeni duruma yakışan bir hüviyete kavuşması ve yeni rejimin modelini teşkil etmesi mecburiyeti doğmuştu. Bu bakımdan şehrin imarına dair birçok kanun ve uygulama hayata geçirilmeye başlanmıştır.

Ankara'da buna uygun olarak öncelikle 1298 tarihli "Ebniye Kanunu" kaldırılmış ve Şubat 1924'de 417 sayılı “Ankara Şehremaneti Kanunu” ile Ankara şehremaneti (belediyesi) kurulması ile işe başlanmıştır (Şenyapılı, 2004: 3).

Ankara Şehremaneti (Belediye) Kanunu'nun ikinci maddesi “İstanbul şehremanetince tatbik edilmekte olan nizamat, talimat ve mukadderattan Ankara şehrinin ihtiyacına uygun olanları cemiyet-i umumiye belediyece tatbik olunur ve 3. maddesi “Ankara Şehremaneti Dahiliye Vekaleti tarafından nasbolunur ve İstanbul şehremininin vazife ve salahiyetine haizdir" denilmektedir

(https://www.tbmm.gov.tr/tutanaklar/KANUNLAR_KARARLAR/ kanuntbmmc002/kanuntbmmc002/kanuntbmmc00200417.pdf).

Ankara Şehremaneti'nin (belediyesi) kurulmasında doğrudan doğruya İstanbul Şehremaneti'ne atıfta bulunularak aynı maddeler, şartlar ile görev ve yetkilerinin de aynen geçerli kabul edilmiş olması Ankara'daki belediye ve imar ihtiyacının aciliyetinin en önemli göstergesidir. Dönemin yöneticilerinin faaliyete geçmek için zaman kaybına tahammüllerinin olmadığı ve uzun uzun düşünmeye ihtiyaç hissetmemiş oldukları anlaşılmaktadır.

Ankara'nın başkent olması dolayısıyla inşasının büyük planlama ve yatırımları gerektirdiği ve bunun da ancak devlet tarafindan gerçekleştirilebileceği için 28.05.1928 tarihinde 1351 sayılı Ankara Şehri İmar Müdürlüğü kurulmuş ve bu müdürlük İçişleri Bakanlığı’na bağlanmıştır (Ankara Şehri İmar Kılavuzu 1946: 5). 
“Ankara Şehri İmar Müdürlügü̈”nün kurulma gerekçesi, Bütçe Encümeni Mazbatasında şöyle açıklanmaktadır, "Cumhuriyet'in başkentinin imarı bir şehir belediyesinin meselesi değil doğrudan doğruya bir devlet meselesidir" (Tankut, 1993. 72).

Daha sonra ise 1.6.1937'den itibaren geçerli olan devir yasası ile Ankara Şehri İmar Müdürlüğü Içiş̧leri Bakanlığı'nın çatısından çıkarılarak Ankara Belediyesine bağlanmıştır (Tankut, 1993. 132).

Ankara Şehri İmar Müdürlügü’nün kuruluş ve görevlerine ilişkin 1351 sayılı kanuna 2.06.1930 tarih ve 1663 sayılı kanunla eklenen maddelerle yangın yerlerine bağlı olmaksızın, Ankara İmar Müdürlügüne her türlü topraklar üzerinde birleştirme, ayırma ve dağıtma yetkisi de verilmişti (Kalabalık, 2003: 184).

Ankara'nın nüfusu her geçen gün hızla artmaktaydı; buna bağlı olarak da konut sıkıntısı ve ihtiyacı acilen çözülmesi gereken bir sorun halini alıyordu. 5228 sayı ve 6.7.1948 tarihli Bina Yapımını Teşvik Kanunu hazinenin ve özel idarenin tasarrufu altındaki arsa ve arazilerin 10 ylllı ödeme planı dâhilinde belediyelere verilmesini esas alıyordu. Söz konusu arsa ve araziler meskeni olmayanlara ve kooperatiflere belirli şartlarla devrediliyordu (Özkaya, 2000: 778). Yine 3194 sayılı İmar Kanununun 8. maddesi de belediyeleri İmar planları yapmakla görevlendiriyordu (Kalabalık, 2003: 73).

Yeni başkentin Batılı ve modern bir şehir modeline uygun olarak yapılandırılması amacıyla bir imar planı hazırlama zarureti de doğmuştu. $\mathrm{Bu}$ projeyi hayata geçirmek amacıyla 1927 yılında uluslar arası bir yarışma düzenlendi ve 1929 yılında Berlin Teknik Üniversitesi Mimarlık Fakültesi'nde öğretim üyesi olan Prof. Hermann Jansen'in imar planı üst düzey bürokratlardan oluşan jüri tarafından birinci olarak ilan edildi.

Zaman içerisinde ortaya çıkan yeni sorunlara çözüm bulmak üzere 14.04.1930'da 1580 sayılı "Belediye Kanunu” hazırlandı (Özkaya, 2000: 956).

Gönül Tankut'un "Bir Başkentin İmarı" adlı eserinde Alexandre'nin "Hâkimiyet-i Milliye"nin 29.03.1933 tarihli nüshasındaki yazısına atıfta 
bulunulmaktadır. Bu makalede, “Türkiye'ye şehircilik Ankara'nın planlı imarı ile gelmiştir. Ankara'nın imarında her girişim bir buluş niteliğindedir. Eğer başarı sağlanırsa Anadolu'nun imarının da temel ilkeleri belirlenmiş olacaktır (Tankut, 1993: 255) denilmektedir.

"Löhler Planı" diye anılan Yenişehir Planı, Şehremaneti’nin kurduğu bir komisyonca kabul edilmiş ve uygulamaya sokulmuştur. Aynı komisyon eski kent düzenlemesini uygulanamaz gerekçesi ile reddetmiştir. İkinci planın kabul edilmesinin nedeni onun beğenilmesinden çok gittikçe tırmanan konut buhranıdır (Tankut, 1993: 54).

1932 y1lında Türkiye Büyük Millet Meclisi'nin onayını alan Jansen'in hazırladığı “Ankara İmar Planı” 1929 Dünya İktisadi Buhranı içerisinde uygulama alanına girdi. 1939 yılında ise II. Dünya Savaşı'nın ağır şartları ve şehir planlamasındaki aksama ve sapmaların da etkisi ile bu faaliyet durduruldu (Tankut,1993: 17).

Ankara'da inşaat işleri 1924-1927'de başlamasına rağmen, ticaret ve hizmet sektörleri 1920'lerin sonlarında, nüfus birikiminin ve halkın alım gücünün belli bir seviyeye yükselmesinden sonra gelişmeye başlamıştır.

1933 tarih ve 2290 sayılı "Belediye Yap1 ve Yollar Kanunu" ile her türlü arsaların plan gereklerine göre belediyelerce bölünmesi, birleştirilmesi sırasında \% 5'lik eksiğiyle dağıtma yetkisi Ankara'daki belediyelere verilmiştir (Kalabalık, 2003: 184). Yine aynı kanun ile belediyeler şehir planları hazırlamakla görevlendirildiler. Konutlar için ruhsatname zarureti getirildi ve ruhsat verme yetkisini de belediyelere verildi (Özkaya, 2000: 782-796). Ayrıca bu kanuna göre belediyelere beldelerinin Dahiliye Vekaletince belirlenen iki farklı ölçüde harita yapma görevi verilmişti. Elli sene içerisindeki nüfus değişimi dikkate alınarak şehir planlarının hazırlanması ve bunun sözkonusu haritalarda gösterilmesi öngörülmüştü.

1939-1944 yılları arasında Erzincan depremi ile başlayıp, ortalama 7 ay gibi kısa aralıklarla meydana gelen ve pek çok vatandaşın ölümüne, 200.000 civarında yapının yıkılmasına neden olan depremler üzerine 22.07.1944 tarih ve 4623 sayılı "Yer Sarsintılarından Evvel ve Sonra Alınacak Tedbirler Hakkında kanun" çıkarılmıştır (Kalabalık, 2003: 265). 
1945 yılında çıkarılan 4758 sayılı kanunla şehir, kasaba ve köylerin kuruluş ve imarı yolundaki plan ve programların gerçekleştirilmesini desteklemek amacıyla kredi sağlayacak olan İller Bankası kurulmuştur (Resmi Gazete, 23.6.1945, Say1: 6039, s.8929-8930).

1946 yılında yayınlanan “Ankara Şehri İmar Kılavuzu”nda CHP Meclis Grubu Komisyonunun Ankara'daki konut sıkıntısını ele alan raporunda memur ve müstahdemlerin mesken sahibi olabilecek durumda olmadıklarından kendilerine arazi tahsis edilmesi ve ev yapmaları için ucuz malzeme temin edilmesi hususu dile getirilmektedir (Ankara Şehri İmar Kilavuzu 1946: 395).

Ankara'da özellikle alt ve orta seviyedeki memurların alım güçlerinin düşüklüğü sebebiyle onların konut ihtiyaçlarını karşılamak üzere yeni tedbirlerin hayata geçirilmesi bir zaruret halini almıştı. 22.06.1948 tarihinde 5218 sayıl1 "Ankara Belediyesine Arsa ve Arazisinden Belli Bir K1sminı Mesken Yapacaklara, 2490 Sayılı Kanun Hükümlerine Bağlı Olmadan ve Muayyen Şartlarla Tahsis ve Temlik Yetkisi Verilmesi Hakkında Kanun" çıkarıldı. Bu kanun meskeni olmayanlara konut yapmak üzere arsa tahsisini ve ruhsatsız meskenlere belirli şartlarla tapu verilmesini esas almaktaydı (Özkaya, 2000: 797-798).

28.6.1948 tarih ve 5228 sayılı "Bina Yapımını Teşvik Kanunu” şehir ve kasabaların imar sınırları içinde hazinenin ve özel idarelerin mülkiyetinde veya devletin hüküm ve tasarrufu altında bulunan arazilerin bedelleri karş1lığında belediyelere devredilmesini esas alıyordu. $\mathrm{Bu}$ kanunla belediyeler tarafından kendisinin veya eşinin üzerinde evi bulunmayanlara ve kooperatiflere arsa tahsis edilecekti (Resmi Gazete, 6.7.1948, Say1: 6950, s. 14321-14322).

Ankara'nın hızla büyümesi yasadışı uygulamaların doğmasını da kolaylaştırmıştı. Ruhsatsız ve kaçak binaların inşa edilmesinin akabinde bu faaliyetlere karşı cezai yaptırımları da gerekli kılmıştır. Bu tarz uygulamalara karşı çıkarılan, 5431 sayı ve 11.6.1949 tarihli kanunla ruhsatsız ve ruhsata aykırı inşaat yapanlar, yaptıranlar, teşvik edenler ve kolaylık gösterenlere ceza yasasının ilgili maddeleri gereğince ceza verilmesi öngörülüyordu (Özkaya, 2000: 781). 
6188 sayı ve 29.07.1953 tarihli "Bina Yapımı Teşvik ve İzinsiz Yapılan Binalar Hakkındaki Kanun" belediyenin mülkiyetinde yahut mülkiyetine geçecek olan arazi ve arsaların mesken yapımına tahsis edilmesini öngörüyordu Bu kanun mesken ihtiyacını karşılamak gayesiyle belediyelere ucuz ve basit mesken imal etme yetkisini veriyordu (Özkaya, 2000: 771772).

1935 y1lı sayımına göre Ankara'nın nüfusu 122.720, 1940'da 157.242, 1945 'de 226.712 ve 1950 'de de 286.781 olarak tespit edilmiştir. 19251935 yılları arasında \% 64, 1935-1940 yıllarında \% 26.7 oranında bir artış gerçekleşmiştir. 1918'de 20.000 civarında olan Ankara nüfusu 32 sene içerisinde 14.3 kat artmıştır (Sarığlu, 2001: 78-79).

\section{Dönemin Türkiye'sinde Köy Gerçeği ve Köye İlişkin Uygulamalar}

Türkiye'de nüfusunun çok ciddi bir kısmını köylüler oluşturmaktaydı ve köy ile şehir veya köylü ve şehirli adeta birbirlerinden farklı iki ayrı dünya idi. Yoğun bir göç hareketinin olmadığ 1 yıllar boyunca gerek iktisadi ve gerekse sosyal ve kültürel yapıları bakımından köylü ve şehirli birbirlerine uzak iki ayrı âlemdi.

1924 tarihinde çıkarılan 442 sayılı "Köy kanunu" ile köy idari bir birim olarak tanımlanırken, köylerdeki idari yapı ile idarecilerin gücü ve yetkileri, köy idarecileri ile köylülerin yapmalarının mecbur tutulduğu veya isteğe bağlı olduğu faaliyetler belirlenmiştir. Bu maddelerdeki köye ilişkin tanım ve tasvirler ile köylülerin yerine getirmeleri mecburi ve isteğe bağlı olarak iki grupta toplanan faaliyetler incelendiğinde, dönemin köylerinin ve köylülerin iktisadi, kültürel ve toplumsal manzarasının çizilmiş olduğu görülmektedir (Resmi Gazete, 7.4.1924, Say1. 68; Düstur, Tertip: 3, Cilt: 5, sayfa 336).

17 Şubat 1925 tarihinde "Așarın İlgası, Yerine İkame Edilecek "Mahsulat-1 Araziye Vergisi Hakkındaki Kanun" ile aşar vergisi kaldırıldı (Okçuoğlu, Önder 1983: 2812). Bu vergininin kaldırılması devleti ciddi bir gelirden mahrum etse de çiftçilerin sermaye birikimi sağlaması bakımından önemli bir kaynak teşkil etmiştir.

Cumhuriyet'in kurulmasını ardından esasen Osmanlı Devleti'nin de temel meselelerinden biri olan eğitim yeni devlet için de öncelikli bir sorun 
haline gelmişti. Özellikle yeni rejimin en ücra yerlere kadar ulaşması, iktisadi kalkınmanın sağlanması ve milli dil ve kültürün köylerde de yaygınlaştırılması arzulanıyordu. Türkiye'de bu alandaki ilk verilerin toplandığı 1935 yılı rakamlarına göre okuma yazma bilenlerin toplam nüfusa oranı \% 19.2'dir. Bunun \% 29.3'ünü erkekler, \% 9.8'ini ise kadınlar oluşturmaktadır. $\mathrm{Bu}$ oranlar 1950 yılında \% 32.5'e çıkmıştır (İstatistik Göstergeler 1923-1990: 5).

1927 yılından itibaren köylere eğitim götürmek üzere Denizli ve Kayseri' de açılan "Köy Muallim Mektepleri" uzun ömürlü olmadı. 1936'da Eskişehir'in Mahmudiye köyünde bir eğitmen kursu açıldı. Amaç; askerde onbaşı, çavuşluk yapmış köylü gençleri altı aylık bir burstan sonra eğitmen unvanıyla küçük köylere ve üç yıllık ilkokullara göndererek öğretmen sıkıntısını biraz hafifletmekti. Bu amaçla İzmir Kızılçullulu ve Eskişehir Çifteler'de Köy Öğretmen Okulları açıldı. Bu okullar daha sonra Köy Enstitüleri'ne dönüştürüldü (Akyüz, 1994: 339).

1945 tarihinde 4753 sayılı “Çiftçiyi Topraklandırma Kanunu” çıkarılmasına rağmen birçok maddesi uygulanamadı. Daha sonra bu kanuna ek olarak yayınlanan 5186 sayılı kanunun da akibeti aynı oldu (Aydemir, 2011: 350$351)$.

\section{Türkiye'de Kırsal Kesimlerden Kentlere Yoğun Göç Hareketi ve Hızlı Kentleşme Süreci}

İkinci Dünya Savaşı'nın ardından bütün dünyada ekonomik ve toplumsal alanda köklü değişimler yaşanmıştır. 1929 dünya ekonomik buhranı gibi Batı dünyasını ve kapitalizmi sarsan bir hadisenin tekrar yaşanmaması için Amerika Birleşik Devletleri başta olmak üzere Batı Avrupa ülkeleri ve büyük şirketler dünyayı bir pazar haline dönüştürmek üzere ticaret yolları ağını genişletmeye ilişkin politikaları devreye koymuşlardı. Aynı zamanda ABD'nin azgelişmiş ve geliş̧mekte olan müttefiklerine yaptı̆g 1 Marshall yardımı ve bu çerçevede hibe edilen tarım makineleri Türkiye'nin iktisadi, kültürel ve toplumsal yapısı üzerinde önemli sonuçlar doğurdu.

$\mathrm{Bu}$ tarihlerden sonra Batı ittifakı içerisinde yer alan yahut buna çabalayan ülkelerde karayolları büyük önem kazandı. Türkiye'de de uygun ve uzun vadeli kredi ve hibelerle desteklenen karayolları hızla inşa edilmeye 
başladı. Karayolları ulaşımı kolaylaştırmasının yanında inşaatlarda çalışan köylülerin şehirle temaslarını da artırmıştır. 1923 senesinde Türkiye'de uzunluğu 18. 335 km olan karayolları, 1940 yılında 40.932 km, 1950'den sonra 47.080 km.'ye ulaştı (Çavdar, 1973: 69-406).

Modern tarım araçları ve aletlerinin yaygınlık kazanması da yine aynı süreç içerisinde gerçekleşmiştir. Türkiye'de 1940 yılında toplam traktör sayıs1 1.066 iken bu rakam 1950'den sonra hızla artarak 16.585 'e çıkmıştır (Türkiye İstatistik Y1llı̆̆ 1996: 313).

Traktör sayısındaki artışa paralel olarak binlerce yıldır Anadolu'da kullanılan karasaban sayısı da her geçen gün düşmüştür. 1955'de 2.123.750 olan karasaban sayısının 1960'da 1.991.259'a indiği görülmektedir. $\mathrm{Bu}$ zaman diliminde sadece traktör sayısında değil, diğer modern tarım aletlerinde de hızlı bir artış söz konusudur. Toprak hazırlama, ekim, sulama, hasat-harman ve nakliyat araçlarının toplam sayısında yıllara göre çok ciddi bir ivme kaydedilmiştir (Türkay, 1968: 87).

Cumhuriyet'ten sonra sağlık alanındaki gelişmeler penicilin gibi ilaçların kullanılması, etkili bir sıtma savaşı, köy sularının sınırlı da olsa kapalı boru sistemleriyle getirilmesi akla gelen koruyucu ve tedavi edici yöntemlerden birkaçıdır. Bunların sonucunda ölüm oranlarında hissedilir bir azalma görülmüştür. Diğer yandan Cumhuriyet kuşağının doğurgan yaşa gelmesi, silah altında olan gençlerin terhisi, evlenme ve doğum sayılarını artırmış, nüfus patlaması meydana gelmiştir (Çavdar, 1973: 69).

\section{Türkiye'de Şehirlerde Ortaya Çıkan Yasadıșı Konut Tipi: Gecekondu}

Kırlardan ve köylerden kentlere doğru süren göç hareketinin ekonomik, toplumsal ve kültürel yansımaları bulunmaktadır. $\mathrm{Bu}$ sorun öncelikle kendisini yerleşim ve konut alanında göstermiştir. Köylerden kentlere göç eden nüfus öncelikle kendisine ait olmayan arsa ve araziler üzerinde derme çatma, tek katlı, elektriği, suyu ve alt yapısı olmayan konutlar inşa etmeye başlamışlardır. Halk arasında "gecekondu" adı verilen bu konutlar daha sonra resmi literatürde de yerini almış ve 1966 yılında ilgili kanunda ifadesini bulmuştur. Gecekondu tabiri kanun maddesinde yer almadan çok önce toplumsal hayattaki yerini çoktan elde etmişti. Bu tabir dönemin gazeteleri, mizah dergileri ve popüler müzik ve filmlerinde yer alarak yaygınlaşmış, sinema, müzik ve edebiyatta ifadesini bulmuştu. 
1966 tarih ve 775 sayılı Gecekondu Kanunu'nun 2. maddesine göre gecekondu şu şekilde tanımlanmıştır: "imar ve yapı işlerini düzenleyen mevzuata ve genel hükümlere bağlı kalmaksızın kendisine ait olmayan arazi veya arsalar üzerinde sahibinin rızası alınmaksızın yapılan izinsiz yapılar" (Resmi Gazete, 30.7.1966, Say1 12362; Düstur, Tertip: 5, Cilt: 5, sayfa 2626).

Ankara'da şehre ilk gelenler iş merkezi ve yerleşik bölgelere en yakın belli oranda eğim, sel yatağı, heyelan bölgesi gibi topoğrafik eşiklerdeki yerleşmeye açılmamış alanlara itilmiş̧lerdir (Şenyapılı, 1996: 2). Bu alanlardaki derme çatma barınaklara baraka denilmektedir. Tansı Şenyapılı, "Baraka'dan Gecekonduya - Ankara'da Kentsel Mekanın Dönüşümü: 1923-1960" adlı eserinde Ankara'da o dönemde yapılan bu konutları ilişkin meseleleri tanımlamak üzere "barakalaşma sorunu" kavramını kullanmaktadır (Şenyapılı, 2004: 97). Aynı zamanda "baraka" kelimesi 486 sayıl1 "Umuru Belediyeye Müteallik Ankam-1 Cezaiyye Kanun"un birinci maddesinde de geçmektedir. Bu kanun maddesinde; "Umuma mahsus mahallerde yapılan "barakalar" ve her nevi inşaat belediyelerce derhal hedmolunur" (Resmi Gazete, 17.05.1924, Kanun No: 486, Say1. 70) denilmektedir.

1940-1950'li y1llarda gecekondular öncelikle Ulus'un kuzeyinde kale çevresindeki yamaçlarda ve civar bölgelerde yaygınlaşmıştır. 1948 yılında bu semtlerde marjinal sektörlerde çalışan 40-60.000 kişi ikamet etmekteydi ve ilgili alanların \% 67'si gecekondulardan oluşmaktaydı (Şenyapılı, 1996: 2-3).

Kemal Kurdaş, Kent-Koop'un Başkent Söyleşileri adıyla yayınladığı eserde yer alan "Eymir'in Çağrısı" başlıklı metninde Ankara'daki gecekondulardan şöyle bahsetmektedir: "1933 yazında Ankara'da ilk gecekondular yeşermeye başlamıştı. Bu gecekondular İkinci Büyük Millet Meclisi binası ve bitişiğindeki halk arasında "Meclis Bahçesi" adıyla tanınan parkın arkasındaki düzlükte ortaya çıkmıştı. O zaman bu mahalleye “Teneke Mahalle" derlerdi” (Kurdaş, 1987: 130).

Gecekondular imar mevzuatına tamamen aykırı olarak ve çok zaman iptidai, konfor ve sağlık şartlarından da mahrum bir şekilde alelacele yapılmış olan meskenlerdir. Mesken dışında dükkân, kahve, depo, garaj 
gibi diğer ihtiyaçlar için de gecekondu yapıldığı görülmekte ise de bunların sayısı çok değildi (Yavuz, 1961: 41). Daha çok hazine, belediye, özel idare gibi kamu alanlarına ait alanlar üzerinde inşa edilen gecekondular özel şahıslara yahut vakıflara ait arazilerin doğuracağı sıkıntılardan dolayı tercih edilmeyen alanlard1.

İkinci Dünya Savaşı yılları ve ardından gelen, dünyada ve ülkemizdeki büyük toplumsal değişmeler, çok partili sistem ve kırlardan kentlere doğru gerçekleşen göç hareketi zaten büyük boyutlu imar planlarının hazırlanmasını ve uygulanmasını zorlaştırmıştır.

Tansı Şenyapılı'nın "Bütünleşmemiş Kentli Nüfus Sorunu” adlı eserinde gecekondu sorununun gazetelere yoğun olarak yansımaya başladığı tarihin 1947 yılı olduğu ifade edilmektedir. Buna göre gecekonduda oturanların niçin gecekondu inşa etmek zorunda kaldıkları, gecekondularda kullanılan inşaat malzemeleri, gecekondu fiyat ve kiraları, gecekondularla ilgili hukuki uygulamalar ve yıkım kararları, gecekonduların sayıları, şehirlerdeki dağılımları, oda sayıları ve oy potansiyelleri ile ilgili yazı ve haberlerden örnekler verilmektedir. Bazı yazılarda da gecekondu bölgelerinin şehir için bir tehdit olarak algılandığı dikkati çekmektedir (Şenyapılı, 1978: 50-56).

1950'den önce İstanbul'daki gecekondu sayısının çeşitli araştırma, anket ve belgelerdeki ölçüm veya tahminlere göre 10.000'i aşmadığı söylenebilir (Yavuz 1961: 45-46).

1950 yılında Türkiye'de 50. 000 gecekondu varken, gecekonduda oturan nüfus 250000 kişi civarındadır (Keleş, 1996: 386). 1950 nüfus sayımı verilerine göre Ankara'da gecekonduda oturan nüfusun 100.000 kişi civarında olduğu ifade edilmektedir. Yine dâhiliye vekili 1958 yılı için Ankara'da bulunan gecekonduların sayısını 45850 ve gecekonduluların sayısını da 222.275 olarak vermiştir (Yavuz, 1961: 47).

Önceleri göçmenlerin devlet arazisinde kendileri için konut yapmalarıyla başlayan bu hareket, yer yer ve zamanla bir ticaret konusu da olmuş 20-25 gecekonduya sahip bir nevi iş adamları da türemiştir (Tümertekin, 1973: 20).

Gecekondu kanunu ile "Gecekondu Tasfiye ve Islah Bölgeleri” ya da "Gecekondu Önleme Bölgeleri” denilen bölgeler belirlenerek halkın 
gecekondu inşasına yönelmesi yerine belirlenen bölgede sağlıklı ve düzenli konutların yapılması sağlanmaya çalışılmış ve bunu gerçekleştirebilmek için de konut yapmak isteyen kişilere birtakım parasal ve teknik imkânların tanınması ve arsa tahsisi yapılması gibi yardım yolları açık tutulmuştur (Kalabalık 2003: 332-333).

\section{Köylerden Şehirlere Göç}

Karayollarının yaygınlaşması, tarım araç ve aletlerinin bilhassa traktör ve pulluk gibi vasıtaların artışı kırlardan kentlere doğru göçün temel sebebidir. Tarım araçları köylerde işsizliği yaratmış, üretim fazlasından doğan ekonomik girdiler geleneksel aile yapılarını parçalamış ve iktisadi zihniyeti değiştirmişti. Öncelikle toprağı olmayan yahut az topraklı köylüler bu süreçten en fazla etkilenen kesimler olduğundan şehirlere ilk göç eden tabakalar bunlar olmuştur.

Kırlardan kentlere doğru göç hareketinin açıklandığı yaygın şemaya göre göç, kırın itişi ve şehrin cazibesi başlıklarında ele alınmaktadır. Kırın itişi, kırdaki iktisadi ve toplumsal meselelere karşılık gelmektedir. Türkiye için bu problemler tarımda modernleşmenin yarattığı işsizlik, kan davası, toprakların aşırı parçalanması ve kırlarda iktisadi kalkınmanın yarattığı zihniyet değişimidir. Şehrin cazibesi ise iş umudu, sağlık ve eğitim hizmetleri, sosyal güvenlik ve refah seviyesindeki artış beklentileri gibi etkenlerden oluşmaktadır.

Türkiye'de iç göçler hakkındaki ilk veriler 1935 Nüfus Sayımında verilmiştir. Ayrıca "başka vilayetlerde doğanlar"ın sayısı bu sayım sonuçları arasında yer almıştır. 1935 yılında nüfusun \% 6.8'i doğdukları vilayetin dişında ikamet ederken, bu oran 1950'ye gelindiğinde \% 8.3'e ulaşmıştır. 1935 yılında doğdukları ilin dışında yaşayan nüfusun daha çok İstanbul, Ankara ve İzmir'de bulunduğu görülmektedir (Tümertekin, 1968: 1-20).

\section{Türkiye'de Şehirleşme Sürece İle Paralel Olarak Gelişen Bir Ürün: Çimento}

Türkiye'nin tarihi aynı zamanda bir boyutu ile șehirleşmenin de tarihidir. Türkiye'deki hızlı kentleşmenin gözlenebileceği diğer bir alan da çimento üretimindeki hızlı artıştır. Çimentonun muhtelif inşaat, bina ve konutlarda 
kullanılması kalkınma ve modernleşmenin de önemli göstergelerinden biridir. Şüphesiz çimento kullanımındaki artış birebir kırdan kente göç süreci ile eşleşmez. Çünkü gecekondu inşaatlarında sadece çimento kullanılmamaktadır.

Türkiye'de 1913 yılında 32.300 ton olan çimento üretim miktarı 1925 yılına kadar aynı seviyelerde kalırken, 1926'dan itibaren gerek üretim, gerekse ithalat miktarında artış kaydedilmiştir. 1926 yılında 94.390 ton olan tüketim miktarı, 1930 'da 137.870 ton, 1938 'de 331.834 ton, 1945 'te de 274.102 ton ve 1949 'da ise 418.000 tona ulaşmıştır. Bundan sadece bir yıl sonra, kullanılan çimento miktarı neredeyse iki misli artarak 816.000 tonu bulmuştur (Şardan, 2012: 8-12).

Türkiye'deki kentleşme hızının en önemli göstergelerinden biri de inşaat sektörünün toplam yatırımlar içerisindeki payıdır. 1950 yılında inşaat yatırımlarının toplam yatırıma oranı \% 67.5 olarak hesaplanmıştır (Özkol, 1971: 51-52).

Yine Türkiye'deki hızlı kentleşme sürecininin bir başka göstergesi de mesleki alanda farklılaşma ve tarım ve hayvancılık gibi daha çok kıra ve köye ait mesleklerin yerini farklı meslek türlerinin almasıdır. 1955 yılının rakamlarına göre ziraat, avcılık, ormancılık ve balıkçılık başlığ 1 altında verilen ve daha çok kır veya köylere ait meslekler \% 77.4'e tekabül ederken, imalat sanayi, inşaat, ticaret gibi şehre ait mesleklerin de \% 22.6'ya karşılık geldiği görülmektedir (İstatistik Göstergeler 1923-1990: $10)$.

\section{Sonuç}

Türkiye Cumhuriyeti kurulduğu tarih itibarıyla yaklaşık onüç milyon nüfusu ve halkının yüzde sekseninin kır veya köylerde ikamet ettiği bir tarım toplumu hüviyetine sahipti. İkinci Dünya Savaşı ve daha çok da 1950'li y1llara kadar şehirlerde imar faaliyetlerinin ötesinde yoğun bir göç ve kentleşme hareketi görülmemekteydi. Bunun tek istisnası başkent olmasının ardından hızla kamu binalarının inşa edilmeye başlandığı, arazi, konut bedel ve kiralarının arttığg Ankara'dır.

Ankara'nın bir başkent olarak inşa edilmesine yönelik planlama faaliyetleri ile birlikte şehircilik açısından yeni kanun ve uygulamaların 
gerçekleştirilmesi zorunluluğu ortaya çıkmıştı. Bu yüzden öncelikle "Ebniye Kanunu" kaldırılarak "Ankara Şehremaniti" ile Ankara Belediyesi kuruldu. “Ankara Şehri İmar Müdürlüğü”nün kurulma gerekçesi de Ankara'nın imarının bir devlet meselesi olarak görülmesiydi.

Ankara'nın imarı yeni Türkiye'nin ve rejimin bir modeli olması bakımından oldukça önemli bir husustu. Esasen Ankara merkezli çıkarılan kanunlar ve uygulamalar bütün ülkeye şehircilik konusunda bilgi ve tecrübe sağlayacaktı.

Ankara'nın hızla büyümesi konut yetersizliğinin yanında öncelikle dar gelirli memurları iktisaden zor duruma düşürüyordu. Devletin bizzat konut yapmasının yanında konut kooperatiflerinin özendirilmesi, arsa tahsisi, kredi verilmisine ve İller Bankasının kurulmasına dair kanunlarla imar faaliyetleri hız kazanmıştır.

Türkiye'nin bir kır toplumu niteliğine sahip olması dolayısıyla köy ile şehir ve köylü ve şehirli birbirinden kopuk iki ayrı dünya halindeydi. Aşar vergisinin kaldırılması devletin gelir kaybına sebep olmakla birlikte köylerde sermaya birikimini sağlamaya yönelik bir hamleydi. 1924 yılında çıkarılan Köy Kanunu ve daha sonra köylere yönelik eğitim faaliyetleri Cumhuriyetin köy politikasının önemli unsurlarıdı.

İkinci Dünya Savaşı'nın ardından başta Amerika Birleşik Devletleri olmak üzere Batı Avrupa ülkeleri 1929 Buhranının tekrar yaşanmaması için dünya ticaret ağının genişletilmesine yönelik hukuki ve toplumsal faaliyetlere giriştiler. Bu yıllarda Batı ittifakı içerisinde yer alabilmek için çok partili hayata adım atan, dış yardım ve uzun vadeli kredilerle karayolları inşaasını devreye sokan ve makineli tarıma geçmeye başlayan Türkiye'de kırlardan kentlere doğru yoğun bir göç hareketi başlamıştı.

Türkiye'de 1950'li yıllardan itibaren yaygınlık kazanacak olan "gecekondu" olgusu bu tarihten önce Ankara'da ortaya çıkmıştı. Ankara' da inşatlarda çalışmaküzere köylerden göç eden işçiler konut sıkıntısı yüzünden acilen şehrin bazı bölgelerine "barakalar" inşa etmeye başlamışlardır. Daha sonra bölge sakinlerinin kalıcı olmaya başlaması ve ailelerini de getirmeleri sürecinde Ankara'nın belirli bölgelerinde ilgili kanunlara rağmen yasadış1, alt yapısı bulunmayan, sağlıksız gecekondu bölgeleri oluşmaya başlamıştır. 
1923’ten 1950'li yıllara kadar Ankara başta olmak üzere sadece birkaç şehirde yüksek olan kentleşme durgun bir seyir izlemiştir. İkinci Dünya Savaşı'nın ardından başlayan hızlı kentleşme ve kırlardan kentlere göç süreci kentlerde konut sorunu başta olmak üzere bir çok toplumsal problemin yaşanmasına yol açmıştır.

Kırlardan kentlere doğru gerçekleşen göç hareketi sonuçlarını ülkemizde daha çok 1960'lardan sonraki yıllarda, 1970'lerde göstermeye başlayacaktır. Yeni kentli tabakaların şehrin kültürel dokusu içerisinde kendi kimliklerini ve taleplerini ifade etmeyle başlayacakları yıllar daha çok 1960 sonrasıdır. Yeni kentliler şehirde tutundukları, ekonomik ve toplumsal hayatta tutunmaya ve ayakta kalmaya başladıkları yıllarda kentin kültürel hayatında da etkili olmaya başlamışlardır. 


\section{KAYNAKÇA}

Akyüz, Yahya (1994). Türk Eğitim Tarihi (Başlangıçtan 1933'e), 5. baskı, İstanbul, Kültür Koleji Yayınları.

- (1946), Ankara Şehri İmar Kılavuzu, Ankara, T.C İmar Müdürlüğü Yayınları.

Aydemir, Şevket Süreyya (2011). İkinci Adam 1938-1950, II. Cilt, 11. özel basım, İstanbul: Remzi Kitabevi.

Baran, Tülay Alim (2003). Bir Kentin Yeniden Yapılanması - İzmir 1923-1938, İstanbul, Arma Yayınları.

Çavdar, Tevfik ve diğerleri (1973), Türkiye'de Toplumsal ve Ekonomik Gelişmenin 5. Yılı, Ankara, Başbakanlık Devlet İstatistik Enstitüsü.

- (1973), 50 Yılda İmar ve Yerleşme 1923- 1973, Ankara, T.C. İmar ve İskân Bakanlığı.

İstatistik Göstergeler - Statistical Indicators 1923 - 1998, 2000, Ankara, TC Başbakanlık Devlet İstatistik Enstitüsü.

İstatistiklerle Türkiye 2002, Ankara, TC Başbakanlık Devlet İstatistik Enstitüsü.

İstatistik Göstergeler - Statistical Indicators 1923 - 1990, Ankara, TC Başbakanlık Devlet İstatistik Enstitüsü Yayını.

Kalabalık, Halil (2008). İmar Hukuku Dersleri - Planlama, Arsa, Yapı, Koruma, Ankara, Seçkin Yayıncılık.

Karpat, Kemal (2003).Türkiye'de Toplumsal Dönüşüm, (Çeviren: Abdulkerim Sönmez), Ankara, İmge Kitabevi Yayınları.

Keleş, Ruşen (1996). Kentleşme Politikası, 3. Baskı, Ankara, İmge Yayınları.

Kurdaş, Kemal (1987). “Eymirin Çağrısı”, Başkent Söyleşileri, Ankara, Kent-Koop Yayınlar1.

Okçuoğlu, Gülsevin ve Önder İzzet (1983), “Aşarın Kaldırılması”, Cumhuriyet Dönemi Türkiye Ansiklopedisi, 10. cilt, İstanbul, İletişim Yayınları.

Özkaya, Eraslan (2000), Açıklamalı ve İçtihatlı İmar Kanunu Şerhi ve Mevzuatı, 2. baskı, Ankara, Seçkin Yayıncılık.

Özkol, Sedat (1971). "Türkiye'de İnşaat Kesiminde Yabancı Uzmanlar ve Firmalar”, Onuncu ve Onbirinci İskân ve Şehircilik Haftası Konferansları- Şehirciliğimizin Bazı Genel ve Özel Sorunları, Ankara, A.Ü SBF Yayınları.

Resmi Gazete, 30.7.1966, Say1 12362; Düstur, Tertip: 5, Cilt: 5, sayfa: 2626. 
Resmi Gazete, 6.7.1948, Say1: 6950, s. 14321-14322.

Resmi Gazete, 23.6.1945, Say1: 6039, s.8929-8930.

Resmi Gazete, 17.05.1924, Kanun No: 486, Say1. 70.

Resmi Gazete, 7.4.1924, Sayı. 68; Düstur, Tertip: 3, Cilt: 5, s. 336.

Sarığlu, Mehmet (2001). Ankara - Bir Modernleşme Öyküsü (1919-1945), Ankara, T.C Kültür Bakanlığı Yayını.

Şardan, Hamdi Serdar (2012). Çimento Sanayinde Ücret Yönetimi - Mukayeseli Bir Analiz, İstanbul, Çimento İşçileri İşverenleri Sendikası Yayını.

Şenyapılı, Tansı (2004). Baraka'dan Gecekonduya: Ankara'da Kentsel Mekanın Dönüşümü (1923/1960), İstanbul, İletişim Yayınları.

Şenyapılı, Tansı (1996). “Ankara’da Gecekondu Oluşum Süreci”, Ankara'da Gecekondu Oluşum Süreci ve Ruhsatlı Konut Sunumu, Ankara, Batıbirlik Yayını.

Şenyapılı, Tansı (1978). Bütünleşmemiş Kentli Nüfus Sorunu, Ankara, Ortadoğu Teknik Üniversitesi Yayını.

Tankut, Gönül (1993). Bir Başkentin İmarı Ankara: 1929-1939, İstanbul, Anahtar Kitaplar Yayınevi.

Tümertekin, Erol (1973). Türkiye’de Şehirleşme ve Şehirsel Fonksiyonlar, İstanbul, İstanbul Üniversitesi Coğrafya Enstitüsü Yayını.

Tümertekin, Erol (1968). Türkiye’de İç Göçler, İstanbul, İstanbul Üniversitesi Coğrafya Enstitüsü Yayını.

Türkay, Orhan (1968). Gizli İşsizlik, Ankara, A.Ü. Siyasal Bilgiler Fakültesi Yayınları.

- (1996), Türkiye İstatistik Yıllığı 1996, Ankara, Devlet İstatistik Enstitüsü Yayını.

- (1977), Türkiye İstatistik Yılı̆̆ı, Ankara, Devlet İstatistik Enstitüsü Yayını.

Yavuz, Fehmi (1961). “Gecekondu Konusu”, Dördüncü İskan ve Şehircilik Haftası Konferansları- 19-21 Nisan 1960, Ankara, A.Ü. SBF Yayınları. s. 41-64.

(https://www.tbmm.gov.tr/tutanaklar/KANUNLAR_KARARLAR/kanuntbmmc002/ kanuntbmmc002/kanuntbmmc00200417.pdf) 